\title{
Research on the Application of Project Management Theory in Innovation and Entrepreneurial Projects
}

\author{
Xiaoyan Li \\ Qingdao Huanghai University, Qingdao, Shandong, 266427
}

\begin{abstract}
At present, many colleges and universities to participate in innovation and entrepreneurship projects, the number of students increased, the number of projects is also increasing in the project reporting, assessment methods, project implementation to the final project conclusion, the entire management process and the amount of information is very large amount of information, So it is necessary to explore a new information management mode to promote the development of college students' innovation and entrepreneurship. There are three parts in this paper.
\end{abstract}

Keywords: Project Management, Innovation and Entrepreneurial, Theory Study

\section{Introduction}

Under the requirements of standardization and standardization of project management theory, students' innovative and entrepreneurial projects can form a set of operational procedures with strong operation, clear procedures and convenient operation. The university applies the theory of project management to carry out standardized and standardized management in the project of college students' innovation and entrepreneurship. It can improve management efficiency, save time, reduce the waste of project resources and avoid duplication of labor. Traditional project management methods are confusing and complicated. Different project management standards are adopted, which complicates project management and greatly increases the difficulty of management. The standardized operation of the project management theory can effectively improve 
the communication efficiency within the project, control the cost of the innovation and start-up project, increase the scientific nature of the project management, shorten the project life cycle and ensure the implementation effect of innovation and entrepreneurship project, And promote the improvement of college students' management ability.

\section{The Current Situation and Problems of Undergraduates' Science Creation Project}

Project reporting is quick, research shallow. At present, the number of participants in innovation and entrepreneurship training projects increased year by year, but the majority of students project results in one to two weeks to complete a short period of time, there is no systematic research, no shape of thinking, the majority of Internet search data, Not really think of some practical action ideas, and then fall on paper, so many projects are too shallow, the feasibility of small, operability is not strong.

Most colleges and universities on student research projects are used to target management approach, our school is no exception, basically only focus on student innovation and entrepreneurship projects to declare the reply, the final answer, and not the actual implementation of the project or not. The lack of the whole process of monitoring the project, the management of funds and project implementation of some of the process of review, resulting in part of the implementation of the project quality is not high. The study did not specify the academic norms and ethics that should be followed and the safety measures to follow when conducting the study, leading to plagiarism and plagiarism, and to ensure safety during the study.

At present, our school for innovation and entrepreneurship training projectoriented results, neglect process. Entirely in the form of a reply, the project person oral narrative and acceptance of the paper based on the results of the project to determine whether the project passed, or poor in good, some projects in the respondent to play a better, more eye-catching, paper The research report was also done excellently, but in fact looks like. The results are not necessarily practical, resulting in students in the implementation of the project more pressure, but also to pay a lot but the results are not ideal student initiative to have a negative impact.

The information construction of the process management of university students' innovation and entrepreneurship projects is not perfect, but only when the project declaration and settlement are simple. The information is not recorded in the course of the project, including the progress of the project, evaluation and so on. Of the management, students found that the problem can not be resolved in time, students can not easily and effectively communicate between the publicity is not high, can not guarantee the authenticity of the project implementation.

Our school has two levels of project management mode: school and college. The school has set up a business start-up and employment office for college 
students. It manages students' project declaration, fund use and project management, while the teachers of the second-level institute carry out specific guidance, To carry out, there is a serious disconnect, not practical for students to carry out entrepreneurial activities.

\section{University students innovation and entrepreneurship project management ideas}

College students to innovate entrepreneurship training program for the promotion of personnel training mode reform of great significance, the school should put together the relevant departments, the Senate responsible for the development of plans to provide financial support to finance, school workers, Communist Youth League is responsible for mobilizing propaganda, entrepreneurship and employment department is responsible for the specific implementation, Establish a school-level organization and coordination body, to develop practical management methods and supporting policies. Under the premise of establishing and perfecting the management mechanism, we can strengthen the organization and leadership of college students and other management in the process of participating in the training project. Increase the investment in the project research infrastructure, the branch should actively participate in students of innovative business projects to provide students with technology, venues, to participate in the project students to provide experimental venues and equipment protection.

Should be innovative entrepreneurship training program into the personnel training programs and teaching plans. In accordance with the regulations, each branch will formulate a work plan for its students' innovative and entrepreneurial training programs according to regulations. At the same time, it may offer some elective courses such as innovative thinking, innovative methods, project management, enterprise management and venture investment. Seriously consider the teacher to guide students to identify the workload of the project, not only for the implementation of the project itself is evaluated, but also on the guidance of teachers assessment, and careful guidance of teachers to give some reward. But also can employ some well-known teachers from other schools, graduates of the school's successful entrepreneurs, entrepreneurs outside the school, to guide students to innovation and entrepreneurship, not only enhance the exchange between the school and enterprise teams, but also conducive to the complementary advantages of both schools and enterprises resources. Open to the whole society, focus on the formation of a relatively stable professional teachers.

Supervision and management of college students' innovation and entrepreneurship training program management, and the implementation of various projects throughout the regulation. To build innovative information network platform for the process of innovation and entrepreneurship training program, to achieve a new information management model. The establishment of a process-oriented project information management and supervision system is to 
effectively promote the innovation and entrepreneurship training program for college students to implement the project is the protection of the project is also a project management training program, The implementation process of authenticity and sustainability of the key conditions conducive to scientific research departments to achieve the whole process of project management.

\section{The Application of Project Management Theory in College Students' Entrepreneurship Project}

The person in charge of the project plays an important management role in the implementation of the project. It is responsible for the coordination, organization and implementation of the project, and the scope of responsibilities of the project members. Project leaders should not only monitor the progress of the project implementation, but also coordinate the team members of the work, such as the application for innovation and entrepreneurship project funds, contact the instructor, to submit reports. It plays an important role in the operation of innovation and entrepreneurship projects for college students. At present, most of the colleges and universities in China's innovation and entrepreneurship projects do not establish a clear system of project leaders. Many project planners have poor coordination ability, can not effectively organize the project members to promote the smooth implementation of the project, can not solve the problems in the operation process of the project, resulting in slow process, and even stop halfway, project implementation effect can not be guaranteed. Therefore, if we want to improve the efficiency of innovation and entrepreneurship projects, we must establish a system of project leader. Project management theory is very concerned about the selection and determination of the project leader, emphasizing the organizational capacity of the project leader. Therefore, the introduction of project management theory in college students' innovation and entrepreneurship projects can effectively promote the smooth progress of the project.

Project management theory will be introduced into university students' innovative and entrepreneurial projects, and their theoretical achievements can be used to guide and manage the projects. It can reasonably allocate project resources such as material, financial and human resources. Make full use of project resources to achieve the optimal allocation of project resources. In a limited budget and time, to ensure the progress of the project implementation, improve project efficiency. Many university students did not fully consider the budget of the project budget. In order to ensure the quality of the project, a large amount of funds was used in the early stage of project implementation, and the funds were wasted, which resulted in the lack of financial support., Causing the project to terminate or delay. At present, most colleges and universities in China's innovation and venture capital funds are more tense, therefore, in the operation of the project need to strictly control the cost of capital. Project management theory emphasizes value management, and through the organization of project activities, 
the wisdom of the team members, the system analysis of project costs and costs, and then planning and coordination, innovative means of operation, the lowest cost to promote the smooth implementation of the project, The process should pay attention to improving the management team members technology. In the project management theory, the value function is equivalent to the cost of the project, therefore, the project operator will seek a powerful way to maximize the effectiveness of cost-effective to ensure project quality. It can be seen that the introduction of project management theory in college students' innovation and entrepreneurship projects can clarify the project implementation objectives, improve the management level of project leaders, make rational use of project resources, avoid duplication of labor and reduce project costs.

Management theory to promote a group in order to complete the project's established goals, and fully develop the sense of team, mobilize the enthusiasm of all members to encourage them to play their respective advantages. At the same time, within the team to a clear division of labor, team members to communicate in a timely manner, work together to complete the project content. At present, some college students have problems of unexplained responsibilities and ineffective communication. Some colleges and universities even have the phenomenon that only the project leaders are doing the work. Other members of the university only have false names and do not participate in any project activities. Therefore, to ensure the successful completion of innovation and entrepreneurship projects, we must use the project management theory, a clear division of labor within the team, the responsibility to the people, and guide members to fully tap their potential and improve team efficiency.

In the early stage of innovation and entrepreneurship projects to strengthen advocacy to guide students to understand the reasons for launching innovative business projects, project content and type, the implementation of the project path, so that students understand the meaning of innovation and entrepreneurship projects for their own development, and the specific process of project implementation. Only in this way can attract the attention of university students, stimulate their participation, encourage law students to put their entrepreneurial ideas into practice, thus promoting the smooth start of innovation and entrepreneurship projects, improve project efficiency. Therefore, colleges and universities must strengthen the promotion of innovation and entrepreneurship projects, innovation and entrepreneurship website can be established to carry out business project talks, posters and publicity boards in the form of related content for students to create a favorable atmosphere for innovation and entrepreneurship.

\section{Conclusion}

In colleges and universities to actively carry out innovation and entrepreneurship projects for college and college students have an important role in promoting. Students participate in innovation and entrepreneurship through the project, can develop their own sense of innovation and entrepreneurship in the project process to enhance their ability to innovate \# \# communication capacity management 
capacity \# coordination, and then after graduation for employment and entrepreneurship to lay a good quality basis. And college students through innovation and entrepreneurship activities, you can enhance the project management capabilities, accumulated management experience, thereby enhancing the ability of daily affairs management. Therefore, most colleges and universities in China are actively carrying out innovation and entrepreneurship projects for college students, has also made gratifying achievements, but overall there are still poor, such as the popularity of propaganda is not enough \# \# \# vague concept of innovative business concepts such as unclear issues. Therefore, the introduction of a set of effective management theory and model has become, college students need to face the important issue of innovation and entrepreneurship projects. The theory of project management, with its distinct theoretical advantages and feasibility, has been applied in many ways. It can effectively reduce the management cost of university students' innovation and start-up projects, improve the environment of innovation and entrepreneurship projects, and ensure the project quality and quantity carry out. At the same time, under the guidance of the project management theory, college students can also innovate management tools, formulate effective means of supervision, and promote the exchange of information within the project, thus ensuring the implementation of the project results.

\section{References}

[1] Liu Bansheng. Independent College of the western region of the scientific and technological innovation capacity of students . Heritage, 16(2), pp. 17-21, 2009. Journal of Mianyang Normal University (Humanities and Social Sciences) "2009[2] Liu Liu. The Cultivation of College Students' Scientific and Technological Innovation Ability, 7(12), pp. 64-66, 2015.

[3] Jiang Yongrong, Li Tianyu, Jiang Dongyun, Nong Yining. Exploration and practice of undergraduate research and innovation team construction mode . Journal of Guilin University of Electronic Technology,72), pp. 16-25, 2007.

[4] Li Yuping, Zhang Fan. Research on SRT and Whole-course Training Mode of Scientific Research Quality of University Students .Journal of Jiangxi Agricultural Sciences, 7(1), pp. 27-35,2006.

[5] Huang Erlie, Wang Xiannong. Study on the Cultivation of College Students' Innovative Ability in Science and Technology - Multiple Classroom . Journal of Hebei University of Engineering, 17(3), pp. 27-35, 2008. 